\title{
Multifocal Synchronous Chromophobe, Papillary, and Clear Cell Renal Cell Carcinoma in a Single Kidney
}

\section{Tek Bir Böbrekte Çok Odaklı Eş Zamanlı Kromofob, Papiller ve Berrak Hücreli Tipte Renal Hücreli Karsinom}

\author{
(D) Joan C. Delto ${ }^{1}$, (D) Siba El Hussein ${ }^{2}$, (D) Brett Fukuma ${ }^{3}$, (D) Alejandro Abello ${ }^{1}$, (D) John Alexis ${ }^{2}$, (D) Luciano Mastrogiovanni ${ }^{3}$, \\ (D) Akshay Bhandari ${ }^{4}$ \\ 'Beth Israel Deaconess Medical Center, Division of Urology, Boston, Massachusetts, USA \\ ${ }^{2}$ Mount Sinai Medical Center, Clinic of Pathology, Miami Beach, Florida, USA \\ ${ }^{3}$ Mount Sinai Medical Center, Clinic of Radiology, Miami Beach, Florida, USA \\ ${ }^{4}$ Mount Sinai Medical Center, Columbia University Division of Urology, Miami Beach, Florida, USA
}

\begin{abstract}
We present a unique case of concurrent chromophobe, clear cell, and papillary renal cell carcinomas (RCC) in three separate sites in the same kidney after partial nephrectomy. We review the literature of synchronous RCC of up to two histologic subtypes, which is rare in occurrence.

Keywords: Chromophobe, Clear cell carcinoma, Papillary, Partial nephrectomy, Renal cell carcinoma
\end{abstract}

$0 \ddot{z}$

Bu çalışmada, parsiyel nefrektomi sonrası aynı böbreğin üç ayrı bölgesinde eş zamanlı kromofob, berrak hücreli ve papiller renal hücreli karsinomu (RHK) olan eşsiz bir olgu sunulmuştur. Eş zamanlı iki histolojik alt tip bile oldukça nadir görülmektedir. Literatür eşliğinde eş zamanlı çoklu alt tip RHK gözden geçirilmiştir.

Anahtar Kelimeler: Kromofob, Berrak hücreli karsinom, Papiller, Parsiyel nefrektomi, Renal hücreli karsinom

\section{Introduction}

Multifocal, synchronous renal cell carcinoma (RCC) in a same kidney is rare. Most case reports describe up to two histologic subtypes of RCC, which were found synchronously with either benign tumors or a primary malignancy of another organ. Given the rarity of this scenario, the long-term prognosis is unknown.

\section{Case Report}

We present a case of a healthy 70-year-old man who was found to have a right renal mass and benign cysts on workup of vague abdominal pain. He denied flank pain, gross hematuria, voiding symptoms, or constitutional symptoms including fever, weight loss, and night sweats. He had no significant medical comorbidities or history of malignancy. He was a non-smoker and had no occupational exposures. He had no family history of urologic malignancies. On examination, he was obese with a body mass index of 36 . His skin was unremarkable without cutaneous lesions. There was neither tenderness nor palpable masses on abdominal examination. His renal function was normal with a creatinine of $1.0 \mathrm{mg} / \mathrm{dL}$ and glomerular filtration rate of 75 .

A computed tomography scan of the abdomen and pelvis with and without intravenous contrast revealed several lesions of the right kidney (Figure 1). In the anterior interpolar region, there was a partially exophytic, heterogenous, solid, enhancing mass (44 to $94 \mathrm{HU}$ ) measuring $3.4 \mathrm{~cm}$, concerning for RCC. There was

Correspondence: Joan C. Delto MD, Beth Israel Deaconess Medical Center, Division of Urology, Boston, Massachusetts, USA E-mail: jdelto@bidmc.harvard.edu ORCID-ID: orcid.org/0000-0002-5685-5775

Received: 18.09.2017 Accepted: 15.10.2017

Cite this article as: Delto JC, Abello A, El Hussein S, Fukuma B, Alexis J, Mastrogiovanni L, Bhandari A. Multifocal Synchronous Chromophobe, Papillary, and Clear Cell Renal Cell Carcinoma in a Single Kidney. J Urol Surg 2018;5(3):200-202.

๑Copyright 2018 by the Association of Urological Surgery / Journal of Urological Surgery published by Galenos Publishing House. 
a $2.2 \mathrm{~cm}$ mildly dense lesion ( $29 \mathrm{HU})$ in the anterior superior pole suggestive of a hemorrhagic/proteinaceous cyst. In the mid to lower pole, there were two adjacent, mildly dense, largely homogenous lesions with no discernable contrast enhancement. The posterior lesion was $4 \mathrm{~cm}$ and exhibited near-fluid attenuation with no enhancement, compatible with a cyst. The anterior lesion was $3.1 \mathrm{~cm}$ with mildly increased density (26 HU) and no significant contrast enhancement $(32 \mathrm{HU}$ ) suggestive of a hemorrhagic/proteinaceous cyst. A bone scan was negative for metastasis.

After extensive discussion, the patient elected to undergo robotic partial nephrectomy of the solid anterior interpolar mass. The other lesions were thought to be benign cysts that did not warrant excision. However, at the time of surgery, while exposing the solid tumor, the lower pole lesion was identified and it appeared to be a complex cystic mass, concerning for malignancy. Thus, both tumors were excised separately. There was a simple cyst in the upper pole that was decorticated and the cyst wall was sent for pathologic examination. All three lesions were removed with a total warm ischemia time of 27 minutes. The remainder of the surgery was unremarkable. He was discharged home on postoperative day two.

Pathologic examination revealed multiple histologic subtypes of RCC. The solid tumor in the interpolar region was composed of eosinophilic cells that were positive for CD117, showed

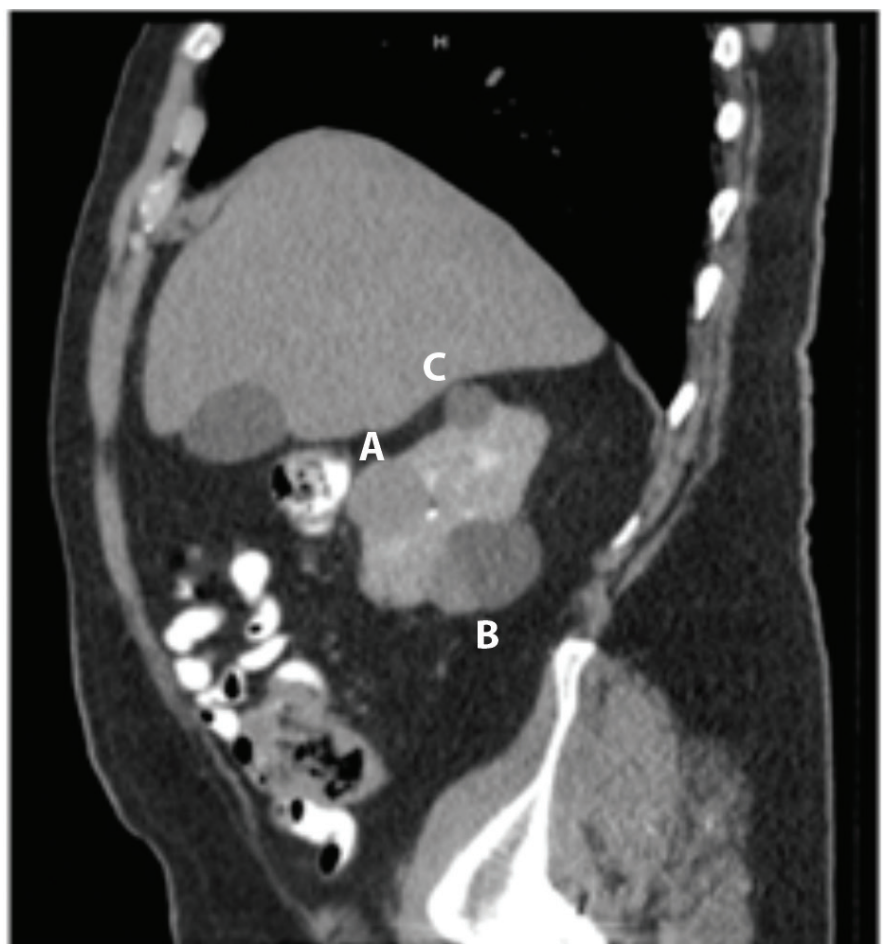

Figure 1. Computed tomography abdomen/pelvis with intravenous contrast. Sagittal view of right kidney with renal lesions: A) Anterior interpolar solid partially exophytic, heterogenous enhancing mass. B) Two adjacent hemorrhagic/proteinaceous cysts. C) Superior pole simple cyst membranous staining for cytokeratin 7 and focal positivity for vimentin, supportive of the diagnosis of eosinophilic variant of chromophobe RCC (Figure 2A). The lower pole tumor was morphologically a papillary RCC, supported by diffuse positive staining for racemase (Figure 2B). The upper pole cyst was a cystic clear cell RCC (Figure 2C). The neoplastic cells were positive for keratin $A E 1 / 3$, paired box gene 8 and vimentin, with a Fuhrman nuclear grade of 1 . All margins were negative.

The patient was seen in follow-up six weeks postoperatively, doing well with excellent renal function. Given such rare pathology and multifocality, the patient may be at higher risk for recurrence. He will be followed with a magnetic resonance imaging three months postoperatively.

Written informed consent was not required at our institution for case report. Patient is not identified.

\section{Discussion}

Synchronous renal tumors of varying pathology in the same kidney is a rare phenomenon. There have been reports of concurrent RCC and benign tumors such as oncocytoma and angiomyolipoma (AML) as well as other primary malignancies such as adrenal $(1,2)$. To our knowledge, this is the first report of multifocal RCC with synchronous tumors of three different histologic subtypes in one kidney: chromophobe, clear cell, and papillary.

There have been only a few case reports of two synchronous RCCs appearing in the same kidney. $\mathrm{Na}$ et al. (3) reported a case of an adult patient with autosomal dominant polycystic kidney disease on hemodialysis who was found to have multiple

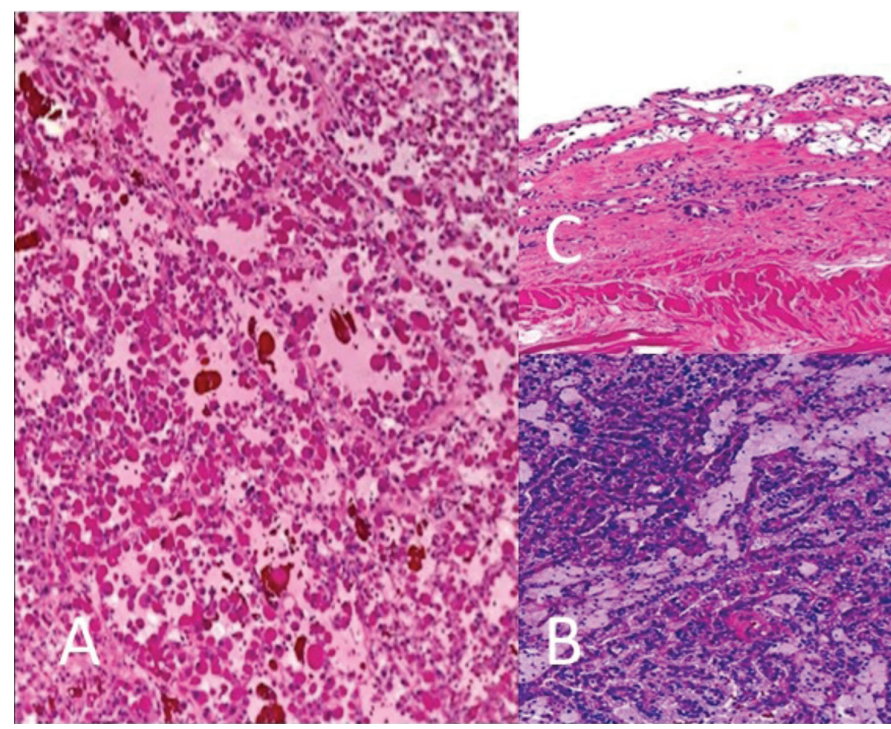

Figure 2. A) Anterior solid lesion with eosinophilic variant of chromophobe renal cell carcinoma. B) Posterior, lower pole lesion with papillary renal cell carcinoma. C) Upper pole cyst with cystic clear cell renal cell carcinoma 
lesions of both papillary and clear cell RCC in the same radical nephrectomy specimen. The patient had no evidence of disease at three-month follow-up. Synchronous chromophobe and papillary RCC has been reported in a solitary kidney with two distinct masses (4). Interestingly, Roehrl et al (5) described a patient with a single $5 \mathrm{~cm}$ renal mass that was found to have components of chromophobe and papillary RCC. Three months after radical nephrectomy, the patient was without evidence of disease.

There have been few reports of synchronous RCCs with AML. Jun et al. (6) reported a radical nephrectomy specimen containing separate lesions including chromophobe RCC, clear cell RCC, and AML. Similarly, Kang et al. (7) reported synchronous chromophobe RCC, clear cell RCC, and an AML in a 62-year-old woman with tuberous sclerosis, who was healthy and without evidence of recurrence six months postoperatively.

The natural history and prognosis for a patient with multiple synchronous RCC lesions of varying subtypes are unknown, given its inherently rare nature. Moreover, the follow-up period of 3-6 months for the patients with two subtypes of RCC in these previously mentioned case reports is short and information about long-term outcome is lacking. All reported patients were treated with radical nephrectomy for multiple tumors. Our patient was treated with partial nephrectomy and found to have negative margins. Our patient may have a potential for worsened prognosis or even a higher likelihood of recurrence given three synchronous types of RCC. Moreover, in the event that adjuvant treatments may be required, regimens may be difficult to determine given the varying nature of each neoplasm. However, since the patient underwent a partial nephrectomy and has excellent renal preservation, the choice of adjuvant therapy is not limited by renal function.

In conclusion, the occurrence of multiple, synchronous, ispilateral renal neoplasms including chromophobe, clear cell, and papillary RCC is rare and prognostic information is not widely available. Thus, careful monitoring and close follow-up of such patients is critical.

\section{Ethics}

Informed Consent: This was not required at our institution for case report. Patient is not identified.

Peer-review: Externally peer-reviewed.

\section{Authorship Contributions}

Surgical and Medical Practices: J.C.D., A.B., S.E.H., J.A., B.F., L.M., Concept: J.C.D., A.B., Design: J.C.D., A.B., Data Collection or Processing: J.C.D., S.E.H., B.F., Analysis or Interpretation: J.C.D., A.B., S.E.H., B.F., L.M., J.A., Literature Search: A.A., J.C.D., Writing: J.C.D., A.B., A.A.

Conflict of Interest: No conflict of interest was declared by the authors.

Financial Disclosure: The authors declared that this study received no financial support.

\section{References}

1. Petrolla AA, MacLennan GT. Renal cell carcinoma and other concurrent renal neoplasms. J Urol 2007;178:2163.

2. Morelli L, Pusiol T, Piscioli I, Larosa M, Pozzoli GL, Monica B. Concurrent occurrence of three primary neoplasms with different hystotype in the same kidney, associated with an adenoma of the omolateral adrenal gland: first case report. Int J Urol 2006;13:1236-1239.

3. Na KY, Kim HS, Park YK, Chang SG, Kim YW. Multifocal renal cell carcinoma of different histological subtypes in autosomal dominant polycystic kidney disease. Korean J Pathol 2012;46:382-386.

4. Tyritzis SI, Alexandrou PT, Migdalis V, Koritsiadis G, Anastasiou I. Synchronous chromophobe and papillary renal cell carcinoma. First report and review of the pathogenesis theories. Pathol Int 2009;59:193-196.

5. Roehrl MH, Selig MK, Nielsen GP, Dal Cin P, Oliva E. A renal cell carcinoma with components of both chromophobe and papillary carcinoma. Virchows Arch 2007;450:93-101.

6. Jun SY, Cho KJ, Kim CS, Ayala AG, Ro JY. Triple synchronous neoplasms in one kidney: report of a case and review of the literature. Ann Diagn Pathol 2003;7:374-380.

7. Kang SG, Ko YH, Kang SH, Kim J, Kim CH, Park HS, Moon du G, Lee JG, Kim JJ, Cheon J. Two different renal cell carcinomas and multiple angiomyolipomas in a patient with tuberous sclerosis. Korean J Urol 2010;51:729-732. 